\title{
Quantifying uncertainties of permafrost carbon-climate feedbacks
}

\author{
Eleanor J. Burke ${ }^{1}$, Altug Ekici ${ }^{2,3}$, Ye Huang ${ }^{4}$, Sarah E. Chadburn ${ }^{2,5}$, Chris Huntingford ${ }^{6}$, Philippe Ciais ${ }^{4}$, \\ Pierre Friedlingstein $^{2}$, Shushi Peng ${ }^{4,7}$, and Gerhard Krinner ${ }^{8}$ \\ ${ }^{1}$ Met Office Hadley Centre, FitzRoy Road, Exeter, EX1 3PB, UK \\ ${ }^{2}$ University of Exeter, College of Engineering, Mathematics and Physical Sciences, Exeter, EX4 4QF, UK \\ ${ }^{3}$ Uni Research Climate and Bjerknes Centre for Climate Research, Bergen, Norway \\ ${ }^{4}$ Laboratoire des Sciences du Climat et de l'Environnement, UMR1572 - CEA-CNRS-UVSQ, 91191 Gif sur Yvette, France \\ ${ }^{5}$ University of Leeds, School of Earth and Environment, Leeds, LS2 9JT, UK \\ ${ }^{6}$ Centre for Ecology and Hydrology, Wallingford, Oxfordshire, OX10 8BB, UK \\ ${ }^{7}$ Sino-French Institute for Earth System Science, College of Urban and Environmental Sciences, Peking University, \\ Beijing, 100871, China \\ ${ }^{8}$ Laboratoire de Glaciologie et Géophysique de l'Environnement, 54 rue Molière, 38402 Saint Martin d'Hères, France
}

Correspondence to: Eleanor J. Burke (eleanor.burke@metoffice.gov.uk)

Received: 14 December 2016 - Discussion started: 5 January 2017

Revised: 24 April 2017 - Accepted: 2 May 2017 - Published: 22 June 2017

\begin{abstract}
The land surface models JULES (Joint UK Land Environment Simulator, two versions) and ORCHIDEEMICT (Organizing Carbon and Hydrology in Dynamic Ecosystems), each with a revised representation of permafrost carbon, were coupled to the Integrated Model Of Global Effects of climatic aNomalies (IMOGEN) intermediate-complexity climate and ocean carbon uptake model. IMOGEN calculates atmospheric carbon dioxide $\left(\mathrm{CO}_{2}\right)$ and local monthly surface climate for a given emission scenario with the land-atmosphere $\mathrm{CO}_{2}$ flux exchange from either JULES or ORCHIDEE-MICT. These simulations include feedbacks associated with permafrost carbon changes in a warming world. Both IMOGEN-JULES and IMOGEN-ORCHIDEE-MICT were forced by historical and three alternative future- $\mathrm{CO}_{2}$-emission scenarios. Those simulations were performed for different climate sensitivities and regional climate change patterns based on 22 different Earth system models (ESMs) used for CMIP3 (phase 3 of the Coupled Model Intercomparison Project), allowing us to explore climate uncertainties in the context of permafrost carbon-climate feedbacks. Three future emission scenarios consistent with three representative concentration pathways were used: RCP2.6, RCP4.5 and RCP8.5. Paired simulations with and without frozen carbon processes were required to quantify the impact of the permafrost carbon feedback on climate change. The additional warming from the permafrost
\end{abstract}

carbon feedback is between 0.2 and $12 \%$ of the change in the global mean temperature $(\Delta T)$ by the year 2100 and 0.5 and $17 \%$ of $\Delta T$ by 2300 , with these ranges reflecting differences in land surface models, climate models and emissions pathway. As a percentage of $\Delta T$, the permafrost carbon feedback has a greater impact on the low-emissions scenario (RCP2.6) than on the higher-emissions scenarios, suggesting that permafrost carbon should be taken into account when evaluating scenarios of heavy mitigation and stabilization. Structural differences between the land surface models (particularly the representation of the soil carbon decomposition) are found to be a larger source of uncertainties than differences in the climate response. Inertia in the permafrost carbon system means that the permafrost carbon response depends on the temporal trajectory of warming as well as the absolute amount of warming. We propose a new policy-relevant metric - the frozen carbon residence time (FCRt) in years - that can be derived from these complex land surface models and used to quantify the permafrost carbon response given any pathway of global temperature change.

\section{Introduction}

The coupling between the global carbon cycle and the rest of the climate system gives rise to a range of feedbacks to cli- 
mate on multiple timescales. These feedbacks are expressed in the future by either amplifying or mitigating any change implied by a given fossil fuel and cement production emission scenario. They are highly uncertain. For example, Jones et al. (2013) showed that inter-model uncertainty in the projected change in land carbon uptake of atmospheric $\mathrm{CO}_{2}$ over the 21 st century is comparable with the implications, on atmospheric $\mathrm{CO}_{2}$, of the spread across emission scenarios. In addition Earth system models (ESMs) do not represent all of the relevant feedbacks. At northern high latitudes, the latest generation of climate models in the Coupled Model Intercomparison Project Phase 5 (CMIP5) ensemble simulate a warming-induced uptake of carbon, albeit with a low confidence (Ciais et al., 2013). However, none of these CMIP5 models include a representation of the large stocks of "old" permafrost carbon. These stocks are currently stabilized by frozen and/or by saturated conditions but may become active and release $\mathrm{CO}_{2}$ or $\mathrm{CH}_{4}$ under global warming (Hugelius et al., 2014; Gorham, 1991). The addition of the permafrostcarbon response to climate may change the CMIP5 model simulations of the northern high latitudes from a sink to a source of carbon and thus a positive feedback (Burke et al., 2013; Koven et al., 2011; Ciais et al., 2013). For this reason permafrost processes must be routinely included in the simulations of the global carbon cycle.

Estimates of the impact of climate change on permafrost carbon have typically been performed combining estimates of soil thermal changes with those of simplified soil carbon decomposition (Burke et al., 2012; Koven et al., 2015a; Schneider von Deimling et al., 2015). Schuur et al. (2015) collated results from many of these studies and showed that the potential carbon release from today's permafrost zone would be between 37 and $174 \mathrm{Gt}$ carbon by the year 2100 under a "business-as-usual" scenario (representative concentration pathway (RCP)8.5; Meinshausen et al., 2011). This is comparable with the later result of Koven et al. (2015a), who estimated a permafrost carbon response of 28-113 Gt C for the same time period and scenario based on a soil carbon decomposition model in which the response of soil carbon to warming was calibrated by the results of laboratory incubation experiments (Schädel et al., 2014).

The response of the land carbon cycle to climate change can be separated into two different components - its response to $\mathrm{CO}_{2}$ and its response to climate approximated by global mean warming (Friedlingstein et al., 2006). The carbonclimate feedback parameter, $\gamma$, defined using the CMIP5 models without permafrost ranges from a release of 16 to $89 \mathrm{Gt} \mathrm{C} \mathrm{K}^{-1}$ from the land surface (Arora et al., 2013). For the CMIP5 models, this is offset by $\mathrm{CO}_{2}$ fertilization of the land surface, making the land surface a net sink. Burke et al. (2013) estimated the permafrost-specific carbon feedback $\left(\gamma_{\mathrm{PF}}\right)$ that was missing in CMIP5 models, i.e. the relationship between the release of carbon from permafrost soils and global temperature change. They estimated $\gamma_{\mathrm{PF}}$ at 2100 to range from an additional release of 6 to $66 \mathrm{GtC} \mathrm{K}^{-1}$.
This is of comparable magnitude to all the other land carbon feedbacks and could change the overall land surface to become a net source of carbon. MacDougall and Knutti (2016) used a permafrost-carbon-enabled intermediate-complexity climate model and confirmed the large magnitude of $\gamma_{\mathrm{PF}}$ but also showed that $\gamma_{\mathrm{PF}}$ increases significantly over time from around $24 \mathrm{GtC} \mathrm{K}^{-1}$ in 2100 to around $47 \mathrm{GtC} \mathrm{K}^{-1}$ in 2300. This suggests that $\gamma_{\mathrm{PF}}$ could be pathway- and timedependent, and the linear feedback approach developed by Friedlingstein et al. (2006) is not valid when incorporating the response of permafrost carbon to warming.

The additional release of permafrost carbon to the atmosphere amplifies global warming forced by anthropogenic emissions, and the amount of permafrost carbon released under various emission scenarios and at different timescales has been estimated in a range of studies (e.g. Schaefer et al., 2011, Koven et al., 2011, 2015a, b). However, there are currently only a few estimates of the impact of this feedback in terms of additional climate change. Burke et al. (2013) and Schneider von Deimling et al. (2012, 2015) used a simple climate energy balance model (EBM) to show the temperature amplification of the permafrost carbon feedback is between 0.02 and $0.36^{\circ} \mathrm{C}$ by 2100 . MacDougall et al. $(2012,2013)$ found that including permafrost carbon within their intermediate-complexity climate model increased the global mean temperature by an additional 0.1 to $0.8^{\circ} \mathrm{C}$ by 2100 . They found the permafrost carbon released under low-emission scenarios provides a more significant climate feedback than the permafrost carbon released under high-emission scenarios. Indeed a kilogram of $\mathrm{CO}_{2}$ transferred to the atmosphere under a low-emissions pathway has a higher radiative efficiency than the same kilogram of $\mathrm{CO}_{2}$ released under a high-emissions pathway. In the MacDougall et al. (2012) study this factor outweighs the more limited permafrost carbon loss at lower emissions. Similarly, using the CLIMBER-2 intermediate-complexity climate model, Crichton et al. (2016) suggest a relative increase of peak temperature change between 10 and $40 \%$, depending on the emission scenario, with RCP4.5 being most affected.

To explore sources of uncertainty in these estimates, we use a coupled climate modelling system of intermediate complexity with next-generation process-oriented land surface models including permafrost processes. This framework allows us to make a more comprehensive assessment of the permafrost carbon response to climate change and its subsequent impact on global temperature, including a wide spectrum of uncertainties of future emissions scenario (policy uncertainty); climate response to increased radiative forcing (climate sensitivity and regional distribution of climate change); and parameterization of the soil carbon decomposition (terrestrial process uncertainty). Three different versions of global land surface schemes (JULESdeepR $R_{\text {resp }}$; JULES-suppressR $R_{\text {esp }}$; and ORCHIDEE-MICT) are coupled with the Integrated Model Of Global Effects of climatic aNomalies (IMOGEN) intermediate-complexity cli- 
mate model (Huntingford et al., 2010). IMOGEN was tuned to represent the response of 22 available global climate models (GCMs) from CMIP3 (phase 3 of the Coupled Model Intercomparison Project). (The range of climate sensitivity (2.1-4.4 K), and regional distribution of climate change in the CMIP3 models is comparable with that in the CMIP5 models (2.1-4.7 K; Andrews et al., 2012).) IMOGEN was run out to 2300 using harmonized emissions scenarios corresponding to RCP2.6, RCP4.5 and RCP8.5 (Meinshausen et al., 2011). This work therefore provides a rigorous assessment of the uncertainty range of the permafrost climatecarbon feedbacks using land surface components representative of the next generation of Earth system models that will be used for the upcoming IPCC assessment.

\section{Materials and methods}

\subsection{JULES land surface scheme}

The Joint UK Land Environment Simulator (JULES; Best et al., 2011; Clark et al., 2011) is the land surface component of the UK Earth System Model (UKESM; Jones and Sellar, 2016). This paper uses a permafrost-adapted version of JULES (version 4.3; Chadburn et al., 2015a). JULES describes the physical, biophysical and biochemical processes that control the exchange of radiation, momentum, heat, water and carbon between the land surface and the atmosphere. It can be applied at a point or over a grid and requires temporally continuous meteorological forcing data along with atmospheric $\mathrm{CO}_{2}$ concentration. Each point or grid box can contain several different land-cover types or "tiles", including five plant functional types (broadleaf trees, evergreen trees, $\mathrm{C}_{3}$ and $\mathrm{C}_{4}$ grasses, and shrubs) as well as non-vegetated tiles (urban, water, ice and bare soil). Each tile has its own surface energy balance, but the soil underneath is treated as a single column and receives aggregated mean fluxes from the surface tiles. TRIFFID, the dynamic vegetation model (Clark et al., 2011), was used to simulate the vegetation distribution and its response in a changing climate.

Several new modifications have been added into JULES to improve the representation of physical and biogeochemical processes in the cold regions. These include the additional impact of the insulation effects of a fractional moss layer at the soil surface; updated soil thermal and hydraulic properties to take account of the presence of organic matter; and a deeper and better-resolved soil column (total depth $18.3 \mathrm{~m}$ ), with an additional thermal column at the base of the soil to represent bedrock (Chadburn et al., 2015a, b). These changes lead to a significant reduction of the error in the annual cycle of soil temperature along with a reduction in the active layer bias, from over $1.0 \mathrm{~m}$ too deep to only about $0.4 \mathrm{~m}$ too deep. All these developments are included here in an improved
JULES version better suited for the permafrost simulations discussed here.

The standard soil carbon model in JULES is a four-pool model (decomposable plant material, resistant plant material, biomass and humus). When added together, these pools represent the total soil carbon storage. The model is based on the RothC soil carbon model and described in detail in Clark et al. (2011). Burke et al. (2017) adapted the soil carbon model in JULES to include a soil vertical dimension within each of the carbon pools. This results in a set of pools in every layer of the soil column. The respiration rate is determined at each depth $(z)$ for each soil carbon pool $(i)$ and is given by

$$
R_{i}=k_{i} C_{i}(z) F_{T}\left(T_{\text {soil }}(z)\right) F_{\mathrm{S}}(s(z)) F_{\mathrm{v}}(v) \exp \left(-z / \zeta_{\text {resp }}\right) .
$$

Here $k_{i}$ is a pool-specific decay constant $\left(\mathrm{s}^{-1}\right) ; C_{i}$ is the amount of soil carbon in pool $i\left(\mathrm{~kg} \mathrm{~m}^{-2}\right)$; and $F_{T}, F_{\mathrm{s}}$ and $F_{\mathrm{v}}$ parameterize the response of the respiration rate to temperature $\left(T_{\text {soil }}(z)\right.$ in $\left.\mathrm{K}\right)$, soil moisture $(s(z)$ as a fraction of saturation) and vegetation fraction $(v)$ respectively. The soil respiration is additionally modified by including an extra exponential decay of respiration with depth. This accounts for factors that are currently missing in the model such as priming effects and microscale anoxia (Koven et al., 2013). The $e$-folding depth $\left(\zeta_{\text {resp }}\right.$ in $\left.\mathrm{m}\right)$ of this function is very uncertain, and the soil carbon vertical distribution depends significantly on its value (Burke et al., 2017). A smaller $\zeta_{\text {resp }}$ means the respiration is more suppressed with depth and results in more soil carbon particularly in the deeper soils.

Two different parameterizations (JULES-suppressR $\mathrm{esp}_{\mathrm{esp}}$ and JULES-deepR $\mathrm{esp}_{\text {}}$ ) of the response of respiration to temperature $\left(F_{T}\right)$ are available within JULES (Clark et al.,

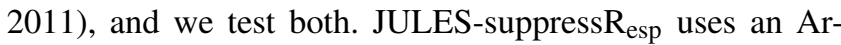
rhenius function $\left(F_{T, Q_{10}}\right.$ from Eq. 2) with $Q_{10}=2.0$ and $\zeta_{\text {resp }}=0.56 \mathrm{~m}$, whereas JULES-deepR $\mathrm{esp}_{\text {esp }} F_{T \text {, Roth }}$ in Eq. (3) and $\zeta_{\text {resp }}=2.5 \mathrm{~m}$. These are shown in Fig. 1 in Burke et al. (2017). Both functions have some decomposition at temperatures below freezing.

$$
\begin{aligned}
& F_{T, Q_{10}}\left(T_{\text {soil }}\right)=Q_{10}^{\frac{T_{\text {soil }}-298.15}{10}} \\
& F_{T, \text { Roth }}\left(T_{\text {soil }}\right)=47.91+\exp \left(\frac{106.0}{T_{\text {soil }}-254.85}\right)
\end{aligned}
$$

Burke et al. (2017) showed there was very little difference in the timing of the peak soil respiration in summer between these two temperature response functions when combined with appropriate $e$-folding depths $\left(\zeta_{\text {resp }}\right)$.

There is a vertical mixing term representing either bioturbation (i.e. the soil mixing by, for example, animals and plant roots) or, in permafrost regions, cryoturbation (soil mixing is from frost heave and freeze-thaw processes). The mixing rate changes depending on whether permafrost is present or not (Burke et al., 2017; Koven et al., 2013). In the absence of permafrost, the bioturbation mixing rate is constant at $1 \mathrm{~cm}^{2} \mathrm{yr}^{-1}$. The cryoturbation mixing rate is set at 


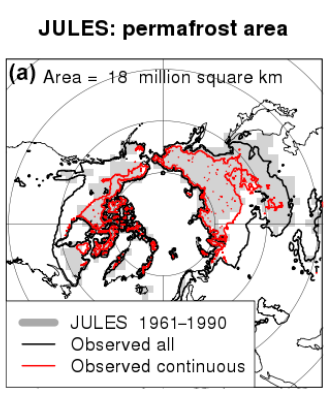

ORCHIDEE-MICT: permafrost area

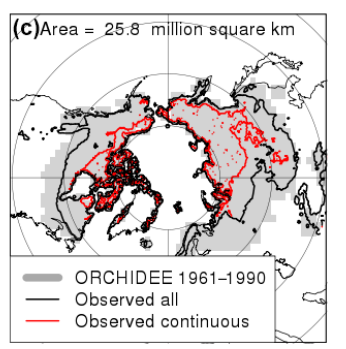

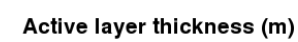

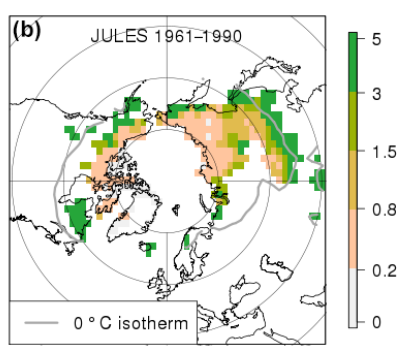

Active layer thickness ( $m$ )

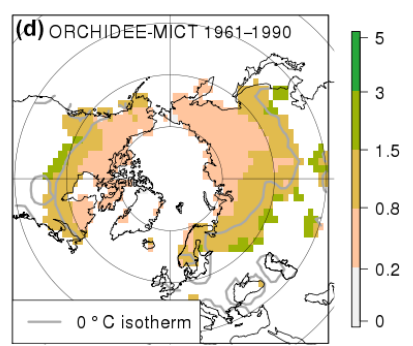

Figure 1. Simulated permafrost extent (a, c) and maximum summer thaw depth $(\mathbf{b}, \mathbf{d})$ for ORCHIDEE-MICT $(\mathbf{c}, \mathbf{d})$ and JULES $(\mathbf{a}, \mathbf{b})$. Superimposed on the simulated extent is the observed permafrost from Brown et al. (1998). Continuous permafrost is where over $90 \%$ of the land surface within the grid cell is underlain by permafrost. The "All" contour includes regions which have some permafrost present in the grid cell. The $0{ }^{\circ} \mathrm{C}$ annual mean isotherm from the WFD 1961-1990 $2 \mathrm{~m}$ air temperature is drawn on the righthand figures.

$5 \mathrm{~cm}^{2} \mathrm{yr}^{-1}$. This drops off linearly below $1 \mathrm{~m}$, reaching zero at $3 \mathrm{~m}$ depth. Permafrost is diagnosed at any location where the deepest soil layer is below $0{ }^{\circ} \mathrm{C}$, assuming that there is only a very minor seasonal cycle in temperature at this depth.

Soil carbon increases, though vegetation litter falls. Although the majority of the litter enters at the soil surface, a small amount enters the deeper soil layers, for example, from roots. In JULES the litter distribution drops off exponentially with depth with an $e$-folding parameter of $5 \mathrm{~m}^{-1}$. The litter is mixed through the soil profile by either bioturbation or cryoturbation. The amount and quality of litter directly impact the soil carbon stocks; therefore it is important for the simulated vegetation distribution to be as accurate as possible.

Using pan-Arctic JULES simulations with this vertically resolved soil carbon model, Burke et al. (2017) showed that, at the large scale, the depth distribution of soil organic carbon approximately follows that of the observations. Chadburn et al. (2017) suggests that, given the correct input (litter), the depth distribution of soil organic carbon is well simulated for mineral soils but that the model is currently unable to reproduce the peat layers of organic soils.

Unique to the analysis is that in JULES a tracer was added to enable the "old carbon" initially within the permanently frozen soils to be easily distinguished from the rest of the soil

carbon (Burke et al., 2017). This enables the old permafrost carbon, defined as carbon within the permanently frozen soil at the start of the simulation, to be traced throughout the simulation.

\subsection{ORCHIDEE-MICT}

Our second land surface model is the Organizing Carbon and Hydrology in Dynamic Ecosystems (ORCHIDEE-MICT) model, again enhanced with several new processes related to cold-region soils. The new soil processes include the implementation of the thermal and hydrological effects of soil freezing in a multi-layered soil hydrology scheme (Gouttevin et al., 2012). Gouttevin et al. (2012) state that the modelling of the soil thermal regime is generally improved by the representation of soil freezing processes. This enables the dynamics of the active layer to be more accurately captured. This process is important when simulating the response of frozen carbon stocks to future warming (Koven et al., 2009, 2011). Also added is a more advanced multi-layer snow scheme, which improves the estimation of permafrost physics (Wang et al., 2013). This three-layered snow module includes a varying snow density and a varying snow thermal conductivity along with the thawing and refreezing of water within the snowpack. More specifically, the snow module has been introduced to account for the water freezing-thawing processes within snow capturing more accurately the impact of the overlying snow cover on soil temperature (Wang et al., 2013). An evaluation of snow depth, snow water equivalent, surface temperature, snow albedo and snowmelt runoff demonstrate the improvement in the simulation of snow processes by this version of ORCHIDEE-MICT over previous versions. To account for the effects of cryoturbation on redistribution of soil organic carbon (SOC), a vertical mixing scheme based on a diffusion equation was introduced into ORCHIDEE-MICT (Koven et al., 2009), with the diffusion length being set to 3 times the local active layer thickness. In the model version used here, carbon and temperature are discretized down to the depth of the bottom layer $(47.6 \mathrm{~m})$, whereas the soil depth for hydrology is $2 \mathrm{~m}$. Soil water content in each layer below $2 \mathrm{~m}$ is assumed to be equal to the monthly average soil moisture at the bottom layer of the top $2 \mathrm{~m}$, and its frozen fraction depends on soil temperature of the layer below $2 \mathrm{~m}$.

The soil carbon model of ORCHIDEE-MICT is based on the equations in the CENTURY model (Parton et al., 1992). It contains seven pools, namely, above- and below-ground metabolic and structural litter, along with active, slow and passive soil organic carbon pools. Decomposition of carbon is modulated by soil temperature and moisture functions along with a clay function. Transfer functions between pools are described using the CENTURY equations (Parton et al., 1992). The temperature function $F_{T}$ follows Eq. (2) for temperatures above $0^{\circ} \mathrm{C}$. At colder soil temperatures below $0{ }^{\circ} \mathrm{C}$, $F_{T}$ is reduced linearly to reach zero at $-1{ }^{\circ} \mathrm{C}$ (Koven et al., 
2011). In this paper, heat production by decomposing soil carbon (the "heating" experiment in Koven et al., 2011) is turned off. Unlike JULES the old carbon cannot be traced throughout the simulation, which means the old carbon below the active layer and within the permafrost is only identified at the start of the simulation. As with JULES, the dynamic vegetation model was used to simulate the vegetation distribution and litterfall. Both of these have a significant impact on the soil carbon stocks.

\subsection{IMOGEN}

The Integrated Model Of Global Effects of climatic aNomalies is an intermediate-complexity climate model developed specifically to quantify geographical and seasonal variation in meteorological conditions over land in response to changing atmospheric gas composition. It can be operated for different anthropogenic-emission scenarios and can capture global land-atmosphere carbon feedbacks. IMOGEN is calibrated to emulate different GCMs and, for example, has recently been used to investigate the risk of Amazon dieback under a large range of climate projections (Huntingford et al., 2013). Here it provides a test bed for evaluating the impact of the permafrost feedback on the global carbon cycle for a variety of emission scenarios, driving GCMs and alternative land surface parameterizations describing the northern latitude terrestrial cryosphere response.

IMOGEN contains a simple energy balance model to relate changes in atmospheric greenhouse gas concentrations to the global mean land temperature via changes in a radiative forcing. The radiative forcing itself depends on any pathway in altered atmospheric gas concentrations since the preindustrial period. The EBM requires four parameters which are readily calibrated against a given climate model (Huntingford et al., 2010). The four parameters are climate feedback parameters over land and over sea, the oceanic effective thermal diffusivity representing the ocean thermal inertia and a land-sea temperature contrast parameter which linearly relates warming over the land to warming over the ocean (Huntingford and Cox, 2000).

IMOGEN forces its coupled land surface model with local meteorological data temporally downscaled from calculated mean monthly values to 30 min timescales using a weather generator. These driving data, required by both JULES and ORCHIDEE-MICT, are $1.5 \mathrm{~m}$ temperature, relative humidity, wind speed, precipitation, downward shortwave and longwave radiation, and pressure. The mean monthly data (that are downscaled) are derived for each GCM, assuming simple linear regressions between the local and monthly variations in meteorology and the amount of annual global mean warming over land. This "pattern-scaling" concept (Huntingford and Cox, 2000) takes these regression values and multiplies them by the mean warming over land calculated from the EBM in IMOGEN. The patterns of changing meteorological conditions plus the four energy balance model parameters to give mean land warming were calibrated for the 22 CMIP3 climate models (Huntingford et al., 2013). These 22 patterns represent the uncertainty in the driving climate models. The monthly anomalies of climate change (from EBM and patterns combined) are added to the 19611990 Water and Global Change forcing data (WFD) climatology (Weedon et al., 2011), which is assumed here to be also representative of pre-industrial conditions. Any biases introduced by neglecting anthropogenically induced climate change up to that date are assumed to be small compared with the errors from using earlier years in the WFD climatology with poorer observational coverage (Huntingford et al., 2013). This also removes individual GCM biases in the estimation of the pre-industrial state.

IMOGEN has a closed global carbon cycle when its operation includes a land surface model (Huntingford et al., 2013). At the end of each modelled year, atmospheric $\mathrm{CO}_{2}$ concentration is modified using the difference between prescribed emissions and the global mean ocean-atmosphere and land-atmosphere fluxes of $\mathrm{CO}_{2}$ for that year. The values of net ecosystem productivity (NEP) are integrated over all land points for that year and used to derive the landatmosphere flux. The NEP is output from either JULES or ORCHIDEE-MICT. A single "box" model is used to calculate the ocean sink. It is a function of both global temperature increase and atmospheric $\mathrm{CO}_{2}$ level (Huntingford et al., 2004). Any changes in atmospheric $\mathrm{CO}_{2}$ concentration then feed back via the energy balance model on modelled surface climate changes, which drives the scaled patterns of local and monthly climatology.

\subsection{Experimental design}

The pre-industrial spin-up state for each of the different land surface models was estimated using the 1961-1990 WFD climatology and pre-industrial atmospheric $\mathrm{CO}_{2}$ concentration at the IMOGEN resolution of $2.5^{\circ}$ latitude and $3.75^{\circ}$ longitude. This was done independently for each of the three different global land surface model configurations, but in each case it was sufficient to give stable soil carbon and vegetation carbon distributions for 1860 . In both JULES and ORCHIDEE-MICT competition of vegetation was enabled, allowing the models to determine both their initial vegetation distributions and litterfall and the response of the vegetation distribution and litterfall to climate change. Anthropogenic land use change was ignored in these simulations, as it is relatively small at northern high latitudes (Klein Goldewijk, 2001).

In JULES a "modified accelerated decomposition" numerical technique (modified-AD; Koven et al., 2013;) was adopted to more quickly spin the JULES soil carbon to an initial equilibrium distribution. The decay rates of the four soil carbon pools were set to the rate of the fastest pool. In order to appropriately adopt the modified-AD method, the diffusion coefficients for the four pools were multiplied 
by the same factors. The model was then initially spun up for 500 model years using this modified-AD technique and the fixed WFD climatology representative of pre-industrial times. The decay rates for the four pools were then reset, and the model was spun up for another 2000 years again using the WFD climatology. This needed to be done independently for both JULES-suppressR $\mathrm{R}_{\text {esp }}$ and JULES-deepR $\mathrm{esp}_{\text {- }}$ although these two model versions have the same physics and vegetation carbon, they have different soil carbon distributions. ORCHIDEE-MICT was initially spun up by running the full version of the land surface model (30 min time step) for 150 years first, again with the WFD climatology. Following this, the soil carbon sub-model forced by above- and below-ground litter input (FORCESOIL) was run 10 times for 10000 model years, with each time followed by a 2-year run of the full ORCHIDEE-MICT. This was followed by another 200 years of ORCHIDEE-MICT to complete the numerical spin-up. Note that, due to its permanent burial of carbon below the active layer even after 100000 years of spinup, ORCHIDEE-MICT's soil carbon pools continue to gain carbon, albeit at a very small rate (mean net ecosystem productivity over the last 50 years of spin-up is $0.16 \mathrm{Gt} \mathrm{C} \mathrm{yr}^{-1}$ ). The permafrost area, soil and vegetation carbon distributions for these pre-industrial states are described here and used to initialize the transient simulations.

To quantify the permafrost carbon feedback separately, paired simulations were carried out for each of the JULES and the ORCHIDEE simulations: one which includes the response of the climate to the $\mathrm{CO}_{2}$ emissions from the perturbed (thawing) permafrost carbon (indexed "PF") and one which excludes it (indexed "non-PF"). In JULES the permafrost carbon and non-permafrost carbon are diagnosed separately at each time step. For the non-PF case, only the non-permafrost carbon is visible to IMOGEN, whereas for the PF simulation all the soil carbon is visible to IMOGEN. In ORCHIDEE-MICT, for the case of the non-PF simulations, the pre-industrial permafrost carbon is subtracted from the total soil carbon at each time step.

The spun-up coupled system is forced with historical fossil fuel and cement production $\mathrm{CO}_{2}$ emissions followed by the emissions representing three of the RCPs used in the Fifth Assessment Report of the Intergovernmental Panel on Climate Change (IPCC AR5; IPCC, 2013) - RCP2.6, RCP4.5 and RCP8.5 (Moss et al., 2010; Meinshausen et al., 2011). Simulations were carried out until the year 2300 using the RCP extensions (Meinshausen et al., 2011) to examine the long-term relationship between permafrost and climate. Non$\mathrm{CO}_{2}$ greenhouse gases and aerosols were not included in this set of simulations, nor were land use change emissions. The impact of these extra emissions will be minor for the purpose of our study focusing on the differences between PF and nonPF simulations.

\section{Results}

\subsection{Evaluation of models}

The models were assessed to ensure that the permafrost physics and the soil and vegetation carbon are not inconsistent with the observations. Permafrost is assumed to exist in grid cells where the soil is frozen at $3 \mathrm{~m}$ depth for a period of 2 years or more. Figure 1 (left panels) shows the simulated permafrost extent for JULES (JULES-suppressR $R_{\text {esp }}$ and JULES-deepR $R_{\text {esp }}$ have the same physics and hence the same permafrost) and ORCHIDEE-MICT. Superimposed on the simulated permafrost extent are the observations from Brown et al. (1998). Both JULES and ORCHIDEE-MICT capture all of the observed continuous permafrost (more than $90 \%$ of a grid cell underlain by permafrost). They might be expected to also capture the regions of discontinuous permafrost (more than $50 \%$ but less than $90 \%$ of a grid cell underlain by permafrost) and simulate a permafrost area similar to the observed area of continuous and discontinuous permafrost $\left(15\right.$ million $\left.\mathrm{km}^{2}\right)$. JULES has slightly too much permafrost overall with extra permafrost in Eurasia and not enough in North America - this is possibly caused by biases in the winter snow depth. ORCHIDEE-MICT systematically simulates more permafrost than either the observations or JULES. Compared with the $0{ }^{\circ} \mathrm{C}$ isotherm for the $2 \mathrm{~m}$ air temperature (Fig. 1, right panels), ORCHIDEE-MICT has some permafrost where the annual mean temperature is greater than $0^{\circ} \mathrm{C}$, suggesting it might be missing a process which increases the thermal insulation in winter between the air and the deeper soil.

The simulated vegetation carbon distribution is shown in Fig. 2. There are no feedbacks from the soil carbon onto the vegetation - via, for example, changing soil hydraulic properties or nitrogen limitation; therefore both versions of JULES also have the same vegetation distribution. In general both of the models simulate more vegetation carbon than observed, which will lead to more litter carbon input. Some model overestimation might be expected because there is no land use change included in the models. There are also some differences in spatial patterns; for example, in JULES the simulated boreal forest does not extend far enough east in Siberia. This will reduce the litter inputs in eastern Siberia and potentially result in relatively smaller simulated soil carbon stocks in these regions. ORCHIDEE-MICT has slightly more vegetation carbon than JULES, but its spatial distribution is more comparable to the observations.

Figure 3 shows the soil carbon distribution simulated by the three different model versions (top three row panels), with the left-hand panels being the total soil carbon in the top $2 \mathrm{~m}$ and the right-hand panels being the soil carbon in the permafrost in the top $3 \mathrm{~m}$. Also shown, bottom row, are two different observational data sets. The first is the ISRICWISE-derived soil property estimates on a 30-by-30 arcsec global grid (WISE30sec; Batjes, 2016). The second is the 

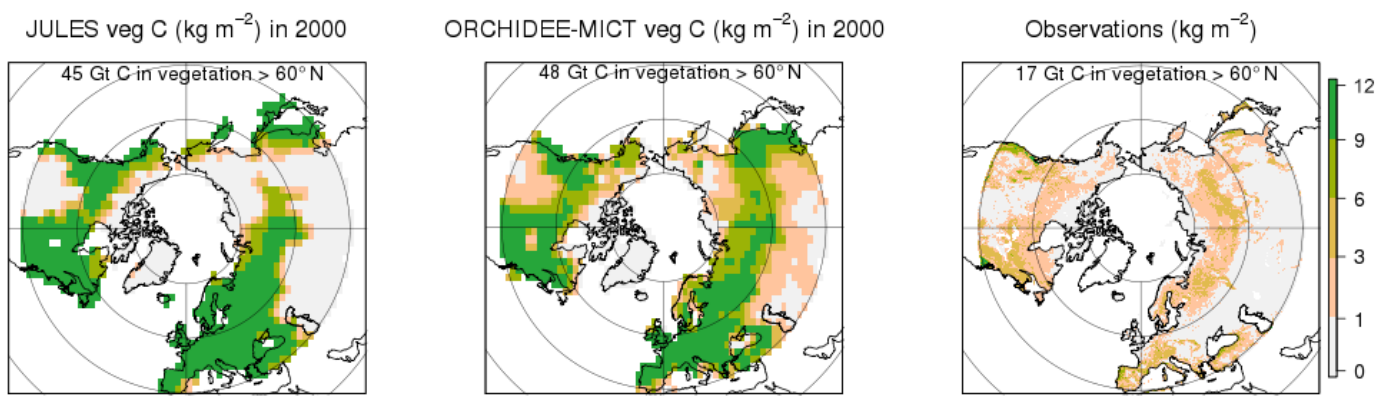

Figure 2. Simulated vegetation carbon distribution for JULES and ORCHIDEE-MICT for the year 2000, and the observations from the IPCC Tier-1 Global Biomass Carbon Map again for the year 2000 (http://cdiac.ornl.gov/epubs/ndp/global_carbon/carbon_documentation.html).

Northern Circumpolar Soil Carbon Database version 2 (NCSCDv2; Hugelius et al., 2014). The WISE30sec soil carbon distribution for the top $2 \mathrm{~m}$ of soil is shown at the bottom left, and the NCSCDv2 for the top $3 \mathrm{~m}$ of the soil is shown at the bottom right. These observed distributions are interpolated from a number of discrete soil pedons and therefore have a large associated uncertainty not reflected in these figures. The two different observational data sets have different amounts of soil carbon in the polar region. In the top $2 \mathrm{~m}$ of the region mapped by the NCSCDv2 there is $873 \mathrm{GtC}$ in NCSCDv2 but only $622 \mathrm{GtC}$ in the WISE30sec data set. The NCSCDv2 was specifically created for the northern high latitudes, so it is likely to be more suitable for any assessment of the northern high-latitude soil carbon, but it only covers a limited region of the northern latitudes.

On inspection of Fig. 3 the models have more soil carbon in the top $2 \mathrm{~m}$ than the WISE30sec observations, but this might be expected if the WISE30sec underestimates the northern high-latitude soil carbon. All three models have large amounts of soil carbon in the permafrost regions of Siberia and northern Canada. The right-hand column shows the simulated soil carbon in the top $3 \mathrm{~m}$ of the simulated permanently frozen soil volume. These are not directly comparable with the NCSCDv2 observations, which show the total soil carbon in the top $3 \mathrm{~m}$; the NCSCDv2 observations provide an upper limit on the permafrost carbon $(586 \mathrm{GtC}$ for regions $>60^{\circ} \mathrm{N}$ ). The permafrost carbon in both JULES simulations falls below this threshold ( 314 and $488 \mathrm{GtC}$ for regions $>60^{\circ} \mathrm{N}$ ), but ORCHIDEE-MICT $(959 \mathrm{GtC}$ for regions $>60^{\circ} \mathrm{N}$ ) has more than the total soil carbon in NCSCDv2.

The simulated distribution of permafrost carbon is strongly controlled by the simulated permafrost extent: ORCHIDEE-MICT has too much permafrost and hence too much permafrost carbon; JULES has too little permafrost in North America and western Russia and consequently low permafrost carbon in that region. Although JULESsuppressR $R_{\text {esp }}$ has suppressed respiration with depth and relatively more soil carbon deeper in the profile, it has a smaller proportion of its total global soil carbon at northern high latitudes than JULES-deepR $R_{\text {esp }}$ because of the dependence of $F_{T}$ on temperature (Eqs. 2 and 3). Despite obvious model biases, these three different models provide reasonable approximations of the land surface state, and we consider them to zero order as suitable for estimating the permafrost carbon feedback.

\subsection{Climate projections}

The simulated areal loss of the top $3 \mathrm{~m}$ or permafrost, or nearsurface permafrost, under the different RCP scenarios considered is shown in Fig. 4. For a grid cell to lose permafrost, it must have a temperature greater than $0{ }^{\circ} \mathrm{C}$ at a depth of $3 \mathrm{~m}$ for at least 1 month of the year. ORCHIDEE-MICT has a much larger initial permafrost extent but loses a smaller fraction of its permafrost than JULES under the RCP scenarios. The models simulate an increasing rate of permafrost loss with time over the next $\sim 100$ years and then tend towards stabilization after 2200 in the RCP scenarios that stabilized forcing around 2100. By 2100 between 5 and $63 \%$ of the permafrost is lost, depending on model configuration and emissions scenario (comparing Fig. 4 changes with annotations in Fig. 1). This potentially very big change in permafrost extent falls within the spread given by Koven et al. (2013) for the CMIP5 models. This might be expected because Koven et al. (2013) found that structural differences in snow physics and soil hydrology had a significant impact on uncertainties - our set of model simulations has a smaller range of these structural uncertainties. Across all scenarios, the near-term sensitivity of future permafrost area to global mean temperature change is 1.95 to 2.10 million $\mathrm{km}^{2}{ }^{\circ} \mathrm{C}^{-1}$ for JULES and 2.30 to 2.55 million $\mathrm{km}^{2}{ }^{\circ} \mathrm{C}^{-1}$ for ORCHIDEE-MICT. This is less than the $4.0 \pm 0.9$ million $\mathrm{km}^{2}{ }^{\circ} \mathrm{C}^{-1}$ found after stabilization of permafrost by Chadburn et al. (2017) but falls within the $1.8-2.6$ million $\mathrm{km}^{2}{ }^{\circ} \mathrm{C}^{-1}$ (Chadburn et al., 2015b) found using transient model simulations. By 2300 between 6 and $90 \%$ of the near-surface permafrost is lost, a range more consistent with the stabilized estimate of Chadburn et al. (2017). In JULES the permafrost area has stabilized by 2300 , but ORCHIDEE-MICT is still losing near-surface permafrost, in particular for the RCP8.5 scenario, suggest- 


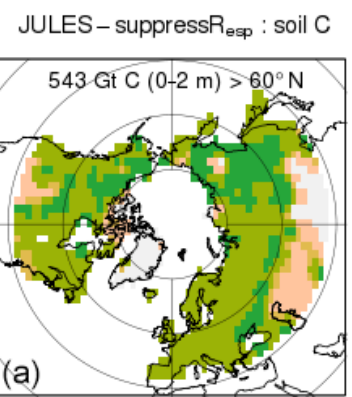

JULES-deepR esp : soil C

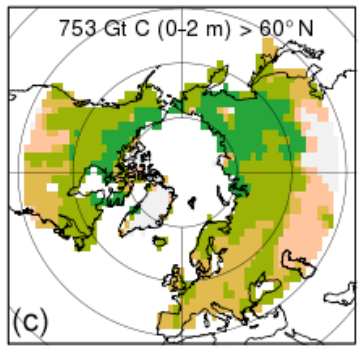

ORCHIDEE-MICT: soil C

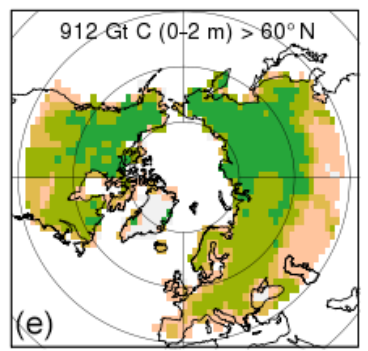

WISE30sec

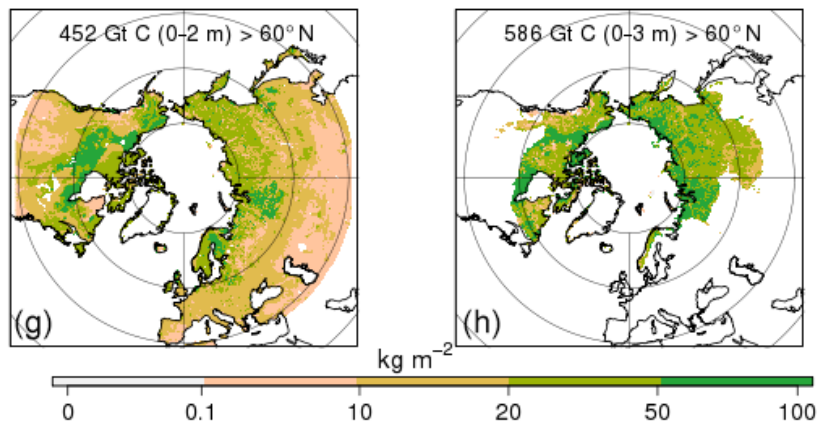

Figure 3. The simulated distribution of soil carbon in the top $2 \mathrm{~m}(\mathbf{a}, \mathbf{c}, \mathbf{e}, \mathbf{g})$ and the permafrost carbon in the top $3 \mathrm{~m}(\mathbf{b}, \mathbf{d}, \mathbf{f}, \mathbf{h})$ for the three different model versions $(\mathbf{a}-\mathbf{f})$. (g, h) show the WISE30sec observed global data set for the top $2 \mathrm{~m}$ (Batjes, 2016: g) and the NCSCDv2 northern high-latitude total soil carbon in the top $3 \mathrm{~m}$ (Hugelius et al., 2014: h). (b, d, f, h) The model simulations show just simulated permafrost carbon, whilst the NCSCDv2 observations show total soil carbon. (a) JULES

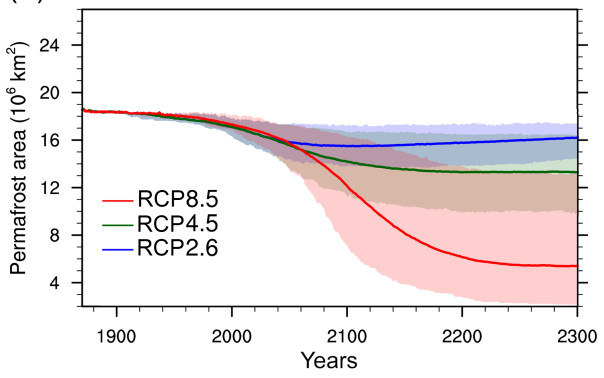

(b) ORCHIDEE-MICT

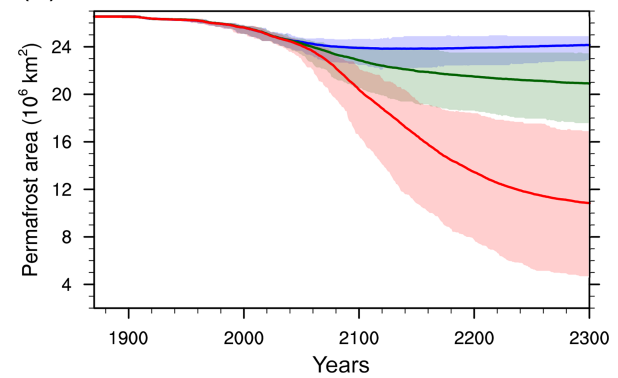

Figure 4. The areal change in simulated permafrost area extent for the JULES and ORCHIDEE-MICT models, and for three different RCP scenarios. The shaded areas in this and subsequent figures represent the full ensemble spread, accounting for uncertainty in climate response across GCMs emulated.

ing that ORCHIDEE-MICT has greater thermal inertia than JULES.

Figure 5 shows the change in northern high-latitude vegetation (top row panels) and soil carbon (middle and bottom) over the region polewards of $60^{\circ} \mathrm{N}$. In the case of soil carbon two different quantities are shown - the non-PF soil carbon in the middle row and the total soil carbon in the bottom row. At the start of the simulation the non-permafrost soil carbon is defined as the soil carbon within the active layer; i.e. any old carbon below the active layer in the permanently frozen soil is excluded. In any given subsequent year, this non-permafrost soil carbon is defined for the same soil volume, i.e. within the active layer defined for 1860 . This nonpermafrost soil carbon is taken to be equivalent to the soil carbon assessed by Ito et al. (2016) and Qian et al. (2010), who present results from simulations of the northern highlatitude carbon balance without any specific permafrost carbon included. The bottom row in Fig. 5 shows the total northern high-latitude soil carbon including both the old carbon below the active layer and the non-permafrost soil carbon. The tables in the Supplement summarize these changes for four different regions (polewards of $60^{\circ} \mathrm{N}$, polewards of $55^{\circ} \mathrm{N}$, the land surface where permafrost is observed and the land surface where permafrost is simulated by each model version in 1860).

Warming and $\mathrm{CO}_{2}$ fertilization effects stimulate vegetation growth and increase land carbon storage in all three land 

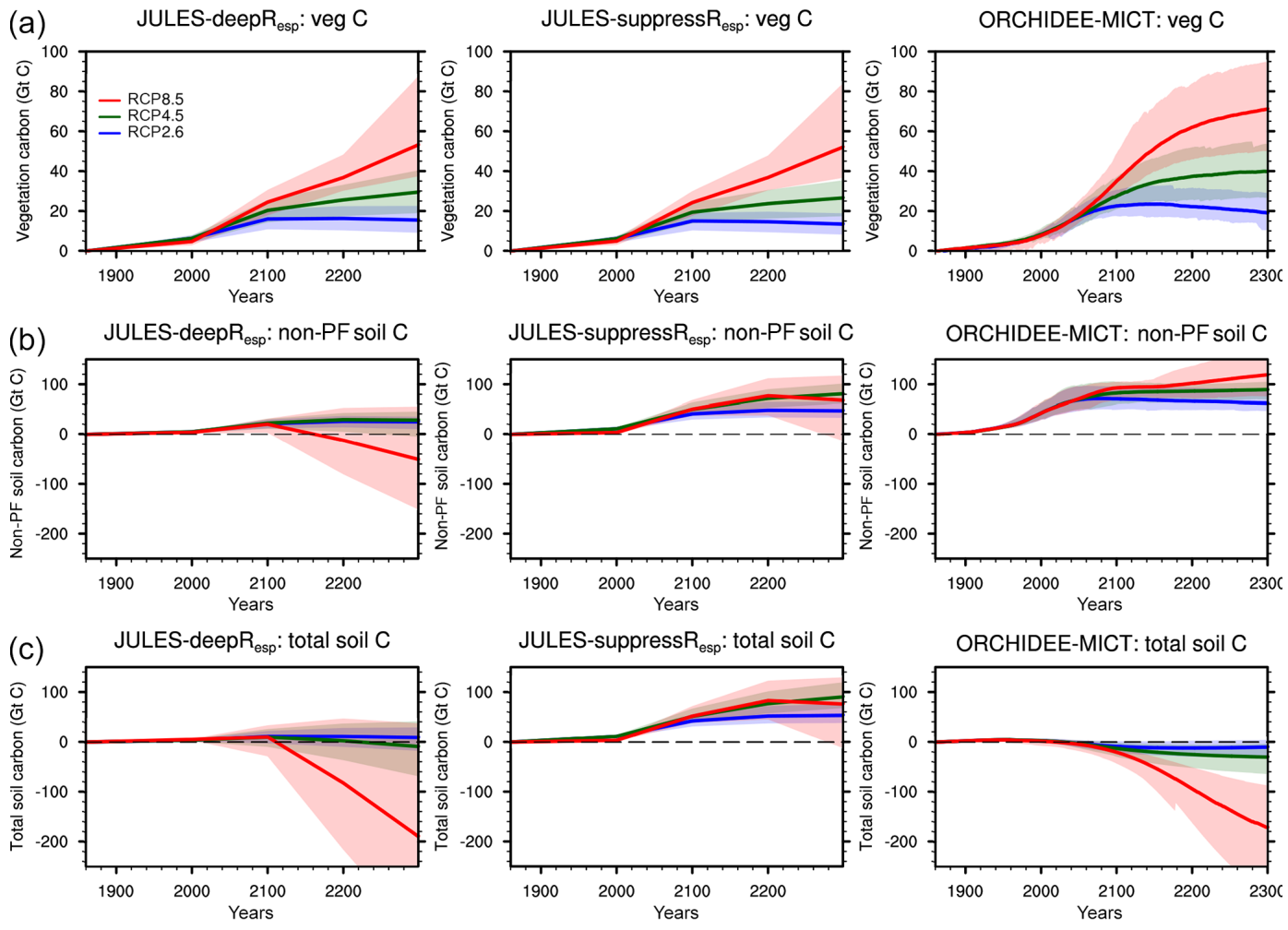

Figure 5. The change in the vegetation carbon (a) non-permafrost soil carbon (non-PF; b) and total soil carbon (c), all for polewards of $60^{\circ} \mathrm{N}$. The vegetation carbon and change are the same in JULES-suppressR $\mathrm{e}_{\mathrm{esp}}$ and JULES-deepR $\mathrm{R}_{\mathrm{esp}}$.

surface model configurations (Fig. 5, top row panels). This results in an increase of vegetation carbon of between 10 and $60 \mathrm{GtC}$ by 2100 with a greater increase in ORCHIDEEMICT than JULES and a greater increase for the higheremissions scenarios, due to higher atmospheric $\mathrm{CO}_{2}$. Ito et al. (2016) used offline land surface models driven by weather data from global climate models under a high-emissions scenario and showed the vegetation carbon change was between -5 and $80 \mathrm{GtC}$ : a much larger spread than found here. Qian et al. (2010) assessed the C4MIP (Coupled Climate Carbon Cycle Model Intercomparison Project) models under a high-emissions scenario and found an increasing vegetation carbon of $17 \pm 8 \mathrm{GtC}$ by 2100 - this range falls within the spread shown here. The vegetation carbon increase is slower in JULES than ORCHIDEE-MICT and continues to increase after 2300, whereas in ORCHIDEE-MICT the vegetation is stabilizing by 2300 . This is probably linked to the different rates of establishment and growth of the boreal forest as it expands polewards in the two models.

This enhanced vegetation productivity leads to increased soil carbon storage in biomass litter and input to soil organic matter pools. In a warming climate, the soil organic matter decomposition also accelerates, decreasing the soil carbon. The balance between increased soil carbon input and increased decomposition (or reduced turnover time of soil carbon) is relatively uncertain (Jones et al., 2005), lead- ing to simulations of either an increase or decrease in nonpermafrost soil carbon at northern high latitudes under future climate change. All three models show an increase in non-permafrost soil carbon before 2100. Across all the different climate responses and emission scenarios examined these increases range from 10 to $100 \mathrm{GtC}$ and suggest that the increase of litterfall dominates over increased respiration. By 2100, Qian et al. (2010) found that the soil carbon in the C4MIP models increases by $21 \pm 16 \mathrm{GtC}$. Ito et al. (2016) showed that, although the majority of their model ensemble members have an increase in soil carbon before 2100 , there are a few with a decrease. This decrease is not reflected in this ensemble of model simulations and is probably caused by a combination of unsampled structural uncertainty in the current ensemble and unrealistic soil organic carbon distributions in some of the models in the Ito et al. (2016) ensemble. The spread of the future response of the non-permafrost soil carbon in RCP8.5 (caused by differences in the driving GCMs) is larger than the differences between the different RCP scenarios. JULES-suppressR $\mathrm{esp}_{\text {and }}$ ORCHIDEEMICT have an increase in non-permafrost soil carbon of similar magnitudes; these increases are slightly larger than in JULES-deepR $_{\text {esp }}$. After 2100 , in the majority of simulations, the non-permafrost soil carbon is relatively stable. The exception to this is RCP8.5 for JULES-deepR $\mathrm{esp}_{\text {, where there }}$ 

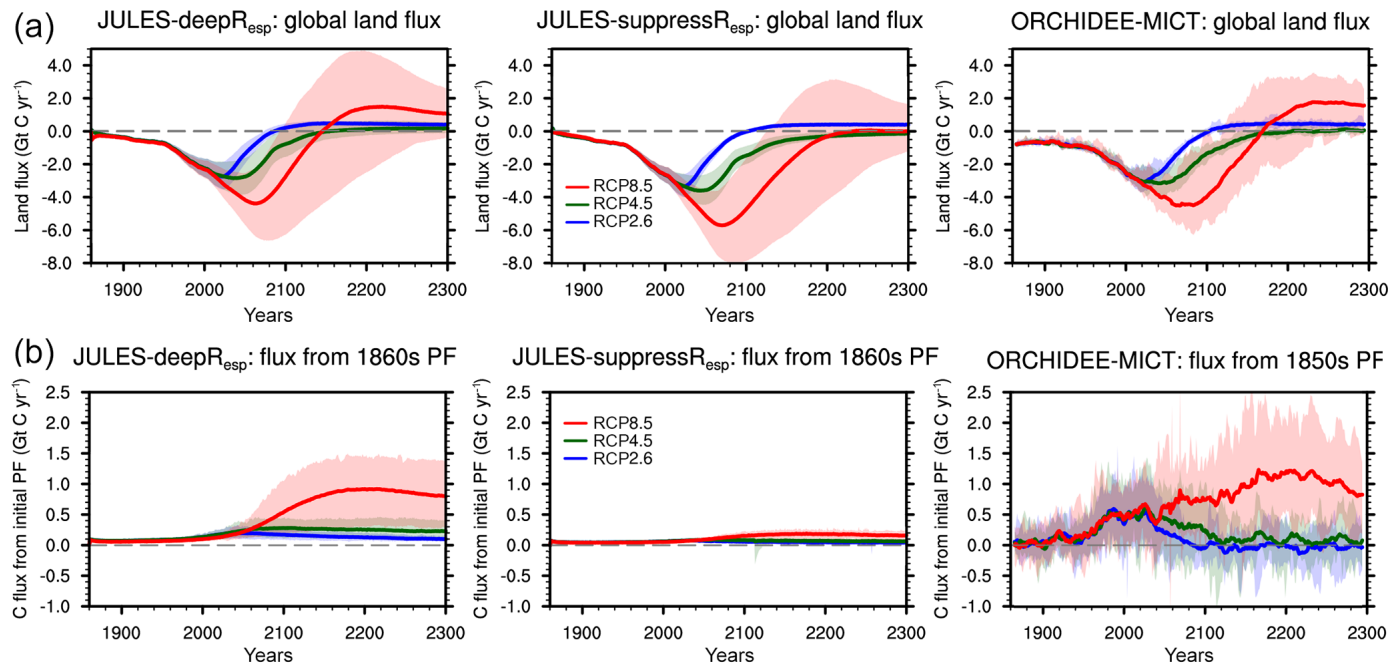

Figure 6. Global land $\mathrm{CO}_{2}$ flux to the atmosphere (positive is a release to the atmosphere) for the permafrost enabled simulations (PF, a). (b) shows the impact of adding permafrost carbon on the global flux of land carbon to the atmosphere, and its associated feedback via the climate system (difference between PF and non-PF simulations, i.e. PF minus non-PF).

is a significant loss of non-permafrost soil carbon for a few of the simulations.

Qian et al. (2010) and Ito et al. (2016) did not include any specific permafrost carbon. However when permafrost carbon is included in the simulations (Fig. 5, bottom row panels), the increase in the total soil carbon before 2100 is reduced, and in some cases there is a slight decrease. The impact of including permafrost soil carbon in northern high-latitude soils is highly model-dependent. In JULESsuppressR $R_{\text {esp }}$, although the total soil carbon increases more than the non-permafrost soil carbon, there is little noticeable difference in Fig. 5. However in ORCHIDEE-MICT and JULES-deepR $R_{\text {esp }}$ there is a significant decrease in total soil carbon compared with non-permafrost soil carbon, which continues past 2300 , especially for RCP8.5. In JULES, uncertainties in the total northern high-latitude soil carbon (given by the spread in the bottom row of Fig. 5) caused by uncertainties in the climate response are larger than the differences between scenarios. However, the differences between the different model versions dominate any differences in scenario or driving climate.

For the ensemble mean of the RCP8.5 scenario, including permafrost carbon in JULES-deepR $R_{\text {esp }}$ and ORCHIDEEMICT results in a reduction in the total carbon in the northern permafrost region by 2150 (when compared with 1860). The majority of the RCP2.6 and RCP4.5 scenarios and JULESsuppressR $R_{\text {esp }}$ still have more total carbon in the northern permafrost region in 2300 than in 1860 , even when permafrost carbon is included.

\subsection{Permafrost carbon feedback}

Changes in biomass and in global soil carbon drive the landatmosphere flux of $\mathrm{CO}_{2}$, which then feed backs, influencing the global climate change. IMOGEN can capture this effect. Globally, there is an initial uptake of carbon by the land, which reduces over time as the vegetation and soil begin to uptake less, and in some cases the soil becomes a source of carbon as respiration carbon loss overtakes litterfall carbon input (Fig. 6, top row panels). By 2300 the global land surface has a net carbon balance very close to zero for many of the RCP2.6 and RCP4.5 simulations. The RCP8.5 simulations are very uncertain, with some climate patterns driving a source of global land carbon and some patterns a sink of global land carbon.

The contribution of permafrost carbon to the global land flux is also shown in Fig. 6 (bottom row panels). Including the permafrost carbon increases the global land $\mathrm{CO}_{2}$ flux to the atmosphere, only slightly for JULES-suppressR $\mathrm{esp}_{\text {sut }}$ more notably for the other two model versions. This brings the time of peak annual uptake earlier in the permafrost enabled simulations - it is 10 years earlier for JULES-deepR $R_{\text {esp }}$ and ORCHIDEE-MICT and 4 years earlier for JULESsuppress $R_{\text {esp }}$ and suggests that permafrost thaw could cause a significant positive feedback on the climate system.

The impact of including these additional permafrostrelated carbon fluxes on the global mean temperature is less than $\sim 0.46{ }^{\circ} \mathrm{C}$ (Fig. 7: PF - non-PF simulations). However, the impact is very different between the three different model

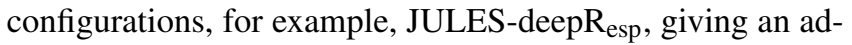
ditional increase of $0.02-0.28^{\circ} \mathrm{C}$ (5th-95th percentile), and JULES-suppressR $R_{\text {esp }}$, giving an additional increase of 0.01$0.05^{\circ} \mathrm{C}$ (5th-95th percentile). These results appear relatively 

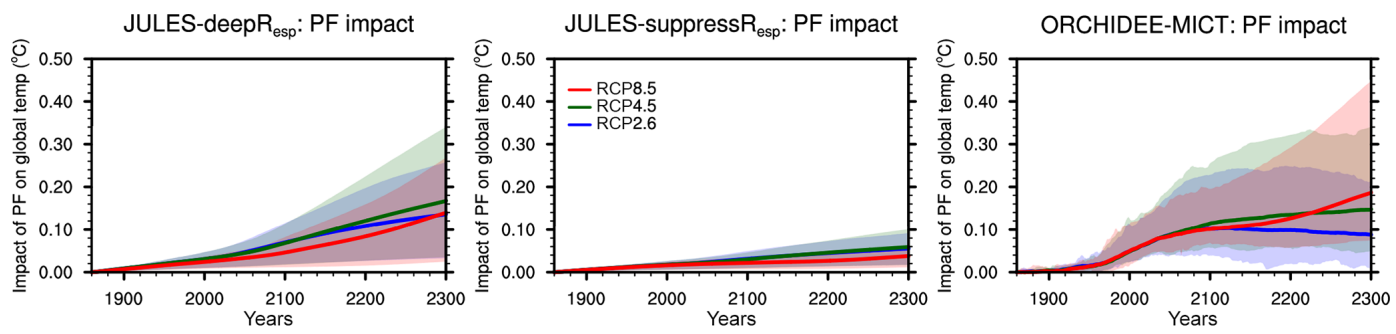

Figure 7. The impact of the permafrost carbon release on the change in global air temperature (PF minus non-PF).
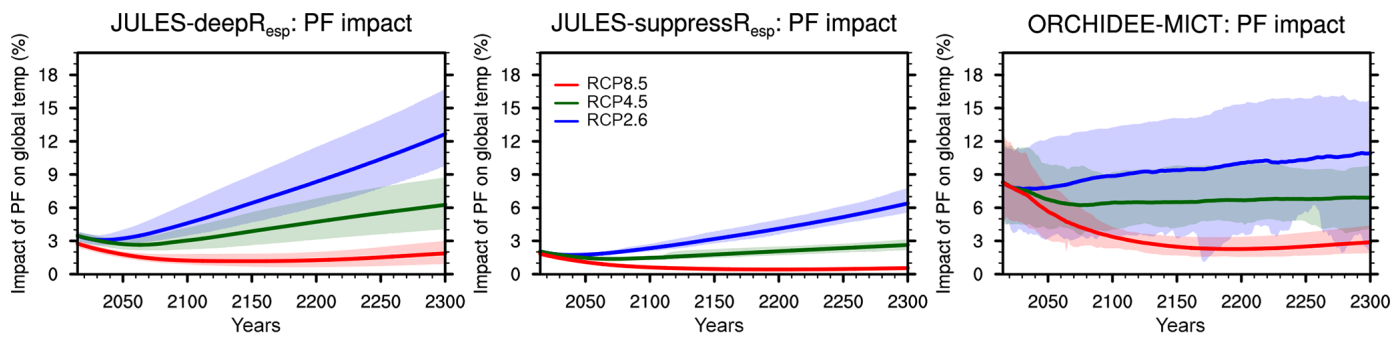

Figure 8. The percentage impact of the permafrost carbon feedback on the global mean air temperature change $(\Delta T)$.

independent of scenario, but there are some notable differences between the different model configurations.

Figure 8 shows the temperature change caused by permafrost carbon loss as a percentage of the global mean temperature change. RCP2.6 has a much lower overall temperature increase $\left(\sim 2^{\circ} \mathrm{C}\right)$ than $\mathrm{RCP} 8.5$ with a ensemble mean temperature increase of $\sim 7^{\circ} \mathrm{C}$. This is reflected by the larger relative impact of the permafrost carbon for the RCP2.6 scenario than for the RCP8.5 scenario. For the RCP2.6 scenario the permafrost carbon loss increases the global mean temperature by between 4 and $18 \%$, however. Even for JULESsuppressR $_{\mathrm{esp}}$, where the loss of permafrost carbon is relatively low, the temperature change caused by permafrost carbon is still a relatively large fraction $(5-8 \%)$ of the global mean temperature change. The percentage impact of permafrost carbon is lower (less than $4 \%$ of the global mean temperature change) for the high-emissions scenario. This is because the radiative forcing from $\mathrm{CO}_{2}$ is a logarithmic function of $\mathrm{CO}_{2}$ concentration - at higher $\mathrm{CO}_{2}$ concentrations, $1 \mathrm{~kg}$ of $\mathrm{CO}_{2}$ increases the radiative forcing less than at lower concentrations. These results, in line with MacDougall et al. (2012) and Crichton et al. (2016), suggest that permafrost carbon should be taken into account particularly when evaluating scenarios of strong mitigation and stabilization.

\subsection{Permafrost carbon climate response}

The carbon cycle response in a changing world can be described via two components, firstly the climate-carbon response $(\gamma)$, which determines the change in carbon storage caused by changes in climate. The climate-carbon response, $\gamma$, is formally defined as the change in land carbon per degree of global mean temperature change (Friedlingstein et al.,
2006). The second component is the concentration-carbon response $(\beta)$, which determines the change in carbon storage caused by changes in $\mathrm{CO}_{2}$ concentration - sometimes referred to as the "fertilization" effect. Chapter 6 of the most recent IPCC report (Ciais et al., 2013) assessed results from models without permafrost carbon and stated that there is high confidence that increasing the atmospheric $\mathrm{CO}_{2}$ will increase land uptake and medium confidence that climate change will reduce the land uptake. The latter can exhibit regional variation, potentially with different signs, and is predominantly due to the direct effects of higher temperatures. The inclusion of permafrost carbon will have a minor impact on the concentration-carbon response $(\beta)$ but will reduce the land carbon uptake and hence increase the climate-carbon response $(\gamma)$.

At the start of the simulation the carbon that is below the active layer is defined as permafrost carbon. In JULES this carbon is numerically labelled, and its (depth) location can be traced throughout the simulation. It is denoted "old permafrost carbon" and is assumed to be the cryogenically stabilized carbon pool within the permafrost under pre-industrial conditions. This can only remain the same or decrease during the simulation period. It cannot be added to. In ORCHIDEE, although the old permafrost carbon can be identified under pre-industrial conditions, it cannot be traced throughout the simulations.

Figure 9 shows the time series of the old permafrost carbon - by 2100 JULES-deepR $R_{\text {esp }}$ loses between 20 and $50 \mathrm{Gt}$ of old permafrost carbon, and JULES-suppressR $\mathrm{R}_{\mathrm{esp}}$ loses about $20 \mathrm{Gt}$ of old permafrost carbon. There are relatively small differences between emissions scenarios compared with the large differences between JULES-deepR $R_{\text {esp }}$ 

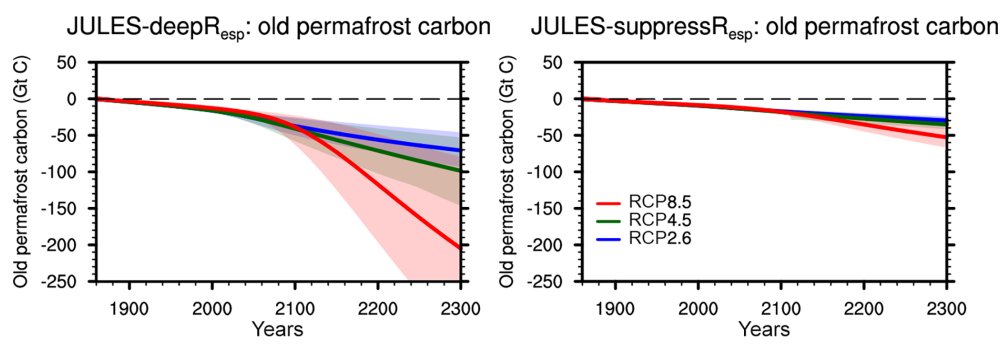

Figure 9. The change in the old permafrost carbon for JULES. Old permafrost carbon is the labelled carbon identified as being within the permafrost at the start of the simulation.

(a) Old permafrost carbon loss: 2100

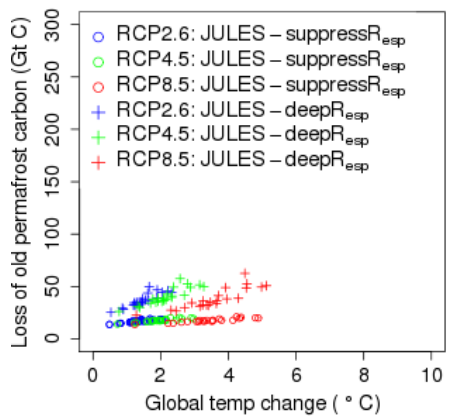

(b) Old permafrost carbon loss: 2200

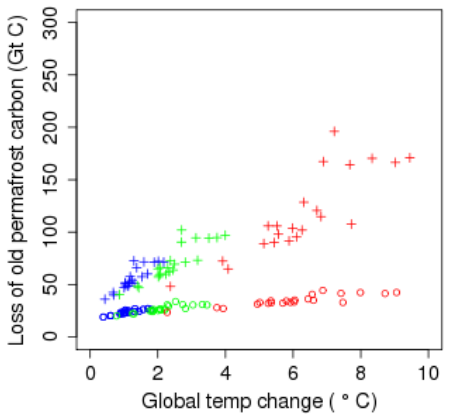

(c) Old permafrost carbon loss: $\mathbf{2 3 0 0}$

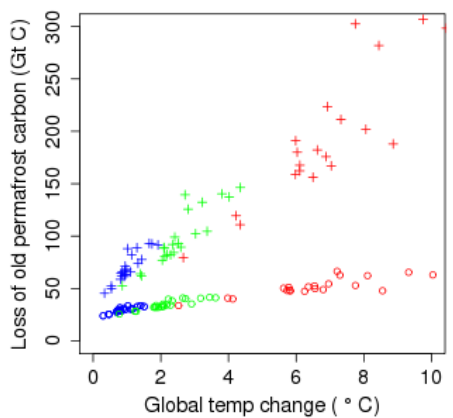

Figure 10. The relationship between the loss of old carbon from the permafrost region and change in global temperature at years 2100,2200 and 2300.

and JULES-suppressR $\mathrm{esp}_{\text {es }}$. Koven et al. (2015b) found a similar result for RCP4.5 with permafrost soil carbon losses of 12.2-33.4 Gt C, but they found a much larger loss of permafrost carbon for RCP8.5, the high-warming scenario. Loss of old permafrost carbon in JULES continues out to 2300, with no sign of stabilization.

Figure 10 shows the change in permafrost carbon as a function of global temperature change for three time slices: 2100, 2200 and 2300. For each time slice and each model version there is a well-defined relationship which is relatively independent of the driving climate model and the emissions scenario. The permafrost carbon-climate feedback parameter, or $\gamma_{\mathrm{PF}}$, is defined as the slope of the relationship between the loss of old permafrost carbon and global mean temperature change, i.e. the slope of the relationship in Fig. 10. $\gamma_{\mathrm{PF}}$ increases with the time over which the warming has been applied; for example, for JULES-deepR $\mathrm{esp}_{\mathrm{esp}}$, $\gamma_{\mathrm{PF}}$ is $\sim 10 \mathrm{GtCK}^{-1}$ at $2100, \sim 20 \mathrm{GtCK}^{-1}$ at 2200 and $\sim 30 \mathrm{GtC} \mathrm{K}^{-1}$ by 2300 . These differences are caused by inertia in the permafrost system related to the ongoing low temperatures which slow the decomposition rate of the thawed old permafrost carbon. This significant time dependence of the permafrost climate feedback (expressed in $\mathrm{GtCK}^{-1}$ ) means that an alternative method of quantifying the permafrost carbon-climate response is required.

\subsection{The frozen carbon residence time (FCRt)}

Here we quantify the FCRt, defined for any time over the simulations as the ratio of remaining permafrost carbon to the permafrost carbon loss rate at that time. FCRt can be used to estimate permafrost carbon loss given any pathway of global mean temperature and an assessment of the initial permafrost carbon. It is derived independently for the two different versions of JULES using the old permafrost carbon traced throughout the simulations and the simulated global temperature change. FCRt is defined for any given year as the old permafrost carbon still in the permafrost divided by the loss of permafrost carbon in that year. Figure 11 shows the FCRt as a function of global mean temperature change (GMT) for the two available versions of JULES. There is a clear relationship between the FCRt and the global mean temperature change. This is relatively independent of scenario but remains highly model-dependent.

The results of an exponential fit between the FCRt and the global temperature change (Eq. 4) are shown in Fig. 11 and Table 1. The data for the fit were restricted so that the global temperature change was between 0.2 and $5^{\circ} \mathrm{C}$, and this relationship should only be applied within that range.

$\mathrm{FCRt}=\mathrm{FCRt}_{0} \exp \left(-\frac{\Delta T}{\Gamma}\right)$ where $\Delta T>0.2^{\circ} \mathrm{C}$ 

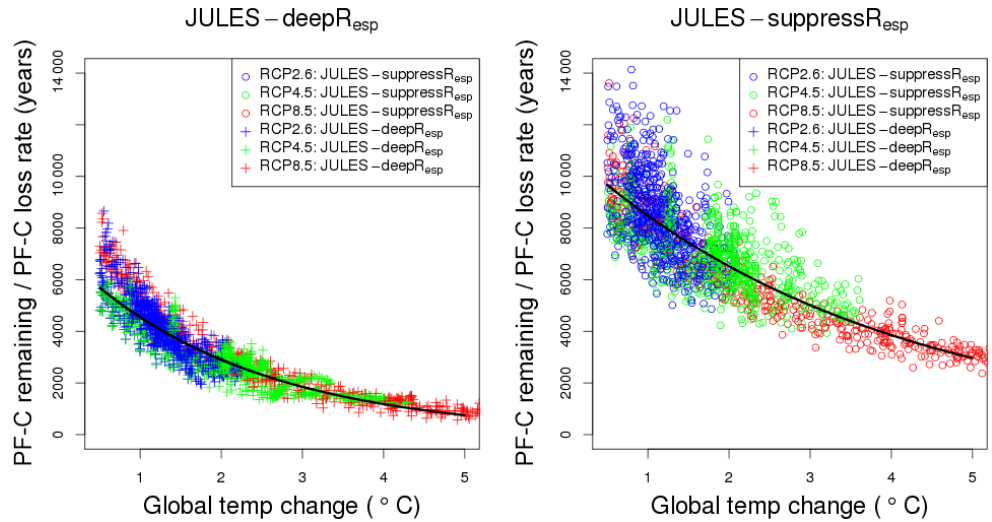

Figure 11. The permafrost carbon remaining in any given year divided by the loss of permafrost carbon in that year (FCRt) as a function of global mean temperature change $(\Delta T)$. The black line is the exponential fit to the model points.

Table 1. Parameters of the exponential fit between permafrost carbon lost per year per remaining permafrost carbon and global mean temperature change (GMT).

\begin{tabular}{lrcc}
\hline Model & $\begin{array}{r}\mathrm{FCRt}_{0} \text { (years; with } \\
\text { GMT =0; Eq. 4) }\end{array}$ & $\begin{array}{c}\Gamma \\
\left({ }^{\circ} \mathrm{C}\right)\end{array}$ & $R^{2}$ \\
\hline JULES-deepR $\mathrm{esp}_{\text {JULES-suppressR }}$ & 6666 & 2.6 & 0.92 \\
esp & 10155 & 4.9 & 0.73 \\
\hline
\end{tabular}

$\mathrm{FCRt}_{0}$ is a reference timescale representing the permafrost carbon turnover time at the transition point from accumulation of soil carbon to loss of soil carbon. $\Delta T$ is the temperature above which this transition occurs. If permafrost carbon were totally inert, $\mathrm{FCRt}_{0}$ would be infinite at $\Delta T=0{ }^{\circ} \mathrm{C}$. However in JULES this is a large but finite number of years, and the old permafrost carbon simulated within JULES can be considered stable over centennial timescales. There are a couple of process within JULES which cause this. Firstly, there is mixing of soil carbon throughout the profile. This mixing reduces exponentially with increasing depth but still occurs within the permafrost. In addition, the soil carbon is still decomposing, albeit at a very slow rate, at temperatures below $0{ }^{\circ} \mathrm{C}$. FCRt $\mathrm{F}_{0}$ is slightly larger for JULES-suppressR $\mathrm{esp}_{\text {esp }}$ because the respiration is much slower at depth than in JULES-deepR $\mathrm{esp}_{\text {sp }}$ The decay term, $\Gamma$, represents the temperature change at which the number of years taken for all of the old permafrost carbon to be emitted reduces by $1 / e$ of its initial value. As expected this is much larger for JULESsuppress $_{\text {esp }}$ than JULES-deepR $R_{\text {esp. }}$.

The relationship found in Eq. (4) can be used to reconstruct a simple estimate to quantify the loss of old permafrost carbon given an annual time series of global mean temperature change and the initial permafrost carbon. An example of a reconstructed time series of permafrost carbon is shown in Fig. 12. The JULES simulations of old permafrost are the in-
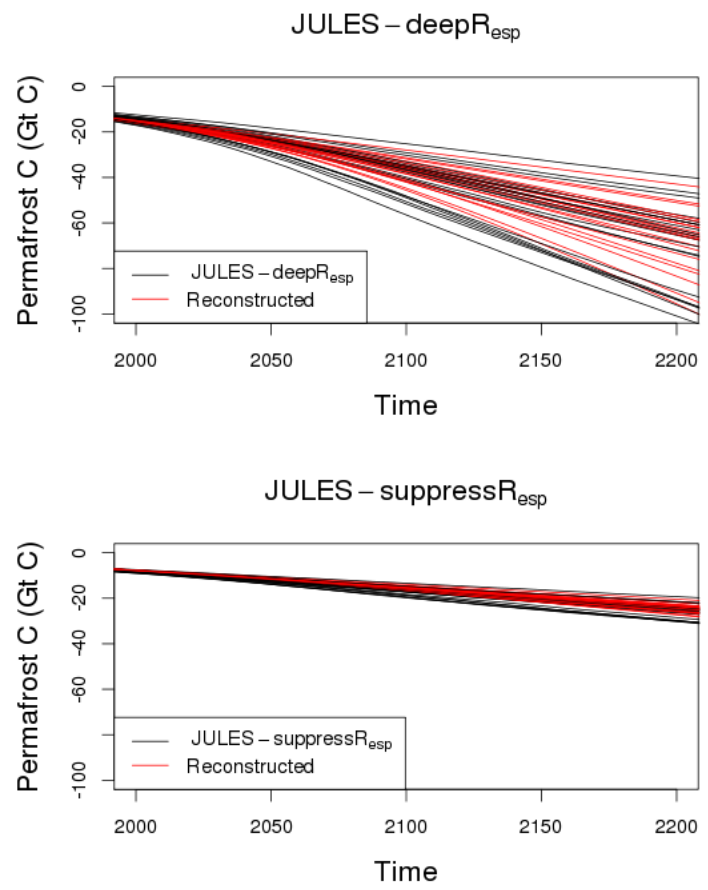

Figure 12. Time series of permafrost carbon loss for the RCP4.5 scenario. The black lines show the JULES simulations, and the red lines show the reconstruction using the initial permafrost carbon, the time series of global mean temperature change and the parameters from Table 1.

dividual curves from Fig. 11 for RCP4.5. The reconstructed curves fall within the spread of the original results.

\section{Conclusions}

This paper uses a coupled climate modelling system of intermediate complexity to project additional temperature increases of 0.005 to $0.2^{\circ} \mathrm{C}$ by the year 2100 and 0.01 to 
$0.34{ }^{\circ} \mathrm{C}$ by the year 2300 caused by our projected permafrost carbon feedback. This is in line with previous results (Schuur et al., 2015). A wide range of uncertainties in the future-emissions scenario (policy uncertainty), driving climate (spread across GCMs) and parameterization of the soil carbon decomposition (process uncertainty) are all sampled. The cause of the largest uncertainty is the structural uncertainty in the soil carbon decomposition process. This highlights the need to increase our understanding of the response of permafrost carbon to temperature change to constrain future projections by utilizing observations of, for example, the depth dependence of the soil carbon residence time or the soil respiration.

There are only a limited number of permafrost-related processes included within the land surface models. In this example the physical response of permafrost to climate change is mainly through a deepening of the active layer. However, in many regions of the northern permafrost region there is a high risk of thermokarst, a process not included in the models. The model structural uncertainty is based around differences in the response of the respiration to temperature. However, there are additional biogeochemical structural model uncertainties such as the partitioning of organic matter into different lability pools along with their turnover times and the dependence of decomposition on moisture, including any differences in these processes between organic rich and mineral soils. In addition, the results described here only include carbon lost in the form of $\mathrm{CO}_{2}$. There will also be carbon lost as $\mathrm{CH}_{4}$ which will feedback into the atmosphere, although this loss of $\mathrm{CH}_{4}$ is likely to impact the permafrost carbon feedback less than the release of $\mathrm{CO}_{2}$ (Schädel et al., 2016). Thawing permafrost is expected to release nitrogen that fertilizes plant growth and offsets some carbon losses. However Koven et al. (2015b) suggest that this has a smaller impact on the projected future carbon balance of the region than the extent of permafrost thaw and decomposability of the soil carbon.

The permafrost carbon feedback has the most significant impact on the mitigation scenario where the temperature change caused by release of permafrost carbon is between 1.5 and $9 \%$ (by 2100) and 6 and $16 \%$ (by 2300) of the global mean temperature change. This has implications for limiting global mean temperature change to 1.5 or $2^{\circ}$, where the permafrost carbon feedback should be included in any analysis of these scenarios. We propose a new metric - the FCRt which can be used to generate the loss of permafrost carbon as a function of global mean temperature change for inclusion into any simple assessment of mitigation scenarios.

Data availability. Model output data are available on request from the authour.

\section{The Supplement related to this article is available online at https://doi.org/10.5194/bg-14-3051-2017-supplement.}

Competing interests. The authors declare that they have no conflict of interest.

Acknowledgements. The authors acknowledge funding and support from the Permafrost in the Arctic and Global Effects in the 21st century (PAGE21) Seventh Framework Programme project GA282700. Eleanor J. Burke was supported by the Joint UK BEIS/Defra Met Office Hadley Centre Climate Programme (GA01101) and CRESCENDO (EU project 641816). Chris Huntingford acknowledges the NERC CEH science budget. Sarah E. Chadburn is grateful to the University of Exeter for access to facilities and was supported by the Joint Partnership Initiative project COnstraining Uncertainties in the Permafrost-climate feedback (COUP) (National Environment Research Council grant NE/M01990X/1).

Edited by: K. Thonicke

Reviewed by: four anonymous referees

\section{References}

Andrews, T., Gregory, J. M., Webb, M. J., and Taylor, K. E.: Forcing, feedbacks and climate sensitivity in CMIP5 coupled atmosphere-ocean climate models, Geophys. Res. Lett., 39, L09712, https://doi.org/10.1029/2012GL051607, 2012.

Arora, V. K., Boer, G. J., Friedlingstein, P., Eby, M., Jones, C. D., Christian, J. R., Bonan, G., Bopp, L., Brovkin, V., Cadule, P., Hajima, T., Ilyina, T., Lindsay, K., Tjiputra, J., and Wuj, T.: Carbon-concentration and carbon-climate feedbacks in CMIP5 Earth system models, J. Climate, 26, 5289-5314, https://doi.org/10.1175/JCLI-D-12-00494.1, 2013.

Batjes, N. H.: Harmonised soil property values for broadscale modelling (WISE30sec) with estimates of global soil carbon stocks, Geoderma, 269, 61-68, https://doi.org/10.1016/j.geoderma.2016.01.034, 2016.

Best, M. J., Pryor, M., Clark, D. B., Rooney, G. G., Essery, R. L. H., Ménard, C. B., Edwards, J. M., Hendry, M. A., Porson, A., Gedney, N., Mercado, L. M., Sitch, S., Blyth, E., Boucher, O., Cox, P. M., Grimmond, C. S. B., and Harding, R. J.: The Joint UK Land Environment Simulator (JULES), model description Part 1: Energy and water fluxes, Geosci. Model Dev., 4, 677-699, https://doi.org/10.5194/gmd-4-677-2011, 2011.

Brown, J., Ferrians Jr., O. J., Heginbottom, J. A., and Melnikov, E. S.: Circum-arctic map of permafrost and ground ice conditions, Digital media, National Snow and Ice Data Center, Boulder, CO (revised February 2001), 1998.

Burke, E. J., Hartley, I. P., and Jones, C. D.: Uncertainties in the global temperature change caused by carbon release from permafrost thawing, The Cryosphere, 6, 1063-1076, https://doi.org/10.5194/tc-6-1063-2012, 2012.

Burke, E. J., Jones, C. D., and Koven, C. D.: Estimating the permafrost-carbon climate response in the CMIP5 climate models using a simplified approach, J. Climate, 26, 4897-4909, 2013. 
Burke, E. J., Chadburn, S. E., and Ekici, A.: A vertical representation of soil carbon in the JULES land surface scheme (vn4.3_permafrost) with a focus on permafrost regions, Geosci. Model Dev., 10, 959-975, https://doi.org/10.5194/gmd-10-9592017, 2017.

Chadburn, S., Burke, E., Essery, R., Boike, J., Langer, M., Heikenfeld, M., Cox, P., and Friedlingstein, P.: An improved representation of physical permafrost dynamics in the JULES land-surface model, Geosci. Model Dev., 8, 1493-1508, https://doi.org/10.5194/gmd-8-1493-2015, 2015a.

Chadburn, S. E., Burke, E. J., Essery, R. L. H., Boike, J., Langer, M., Heikenfeld, M., Cox, P. M., and Friedlingstein, P.: Impact of model developments on present and future simulations of permafrost in a global land-surface model, The Cryosphere, 9, 1505-1521, https://doi.org/10.5194/tc-9-1505-2015, 2015b.

Chadburn, S., Burke, E., Cox, P., Friedlingstein, P., Hugelius, G., and Westermann, S.: An observation-based constraint on permafrost loss as a function of global warming, Nat. Clim. Change, 7, 340-344, https://doi.org/10.1038/nclimate3262, 2017.

Ciais, P., Sabine, C., Bala, G., Bopp, L., Brovkin, V., Canadell, J., Chhabra, A., DeFries, R., Galloway, J., Heimann, M., and Jones, C.: Carbon and other biogeochemical cycles, in: Climate Change 2013: The Physical Science Basis, Contribution of Working Group I to the Fifth Assessment Report of the Intergovernmental Panel on Climate Change, Cambridge University Press, Cambridge, 465-570, 2014.

Clark, D. B., Mercado, L. M., Sitch, S., Jones, C. D., Gedney, N., Best, M. J., Pryor, M., Rooney, G. G., Essery, R. L. H., Blyth, E., Boucher, O., Harding, R. J., Huntingford, C., and Cox, P. M.: The Joint UK Land Environment Simulator (JULES), model description - Part 2: Carbon fluxes and vegetation dynamics, Geosci. Model Dev., 4, 701-722, https://doi.org/10.5194/gmd-4701-2011, 2011.

Crichton, K. A., Bouttes, N., Roche, D. M., Chappellaz, J., and Krinner, G.: Permafrost carbon as a missing link to explain $\mathrm{CO}_{2}$ changes during the last deglaciation, Nat. Geosci., 9, 683-686, https://doi.org/10.1038/ngeo2793, 2016.

Friedlingstein, P., Cox, P., Betts, R., Bopp, L., Von Bloh, W., Brovkin, V., Cadule, P., Doney, S., Eby, M., Fung, I., and Bala, G.: Climate-carbon cycle feedback analysis: Results from the C4MIP model intercomparison, J. Climate, 19, 3337-3353, 2006.

Gorham, E.: Northern peatlands: role in the carbon cycle and probable responses to climatic warming, Ecol. Appl., 1, 182-195, 1991.

Gouttevin, I., Krinner, G., Ciais, P., Polcher, J., and Legout, C.: Multi-scale validation of a new soil freezing scheme for a landsurface model with physically-based hydrology, The Cryosphere, 6, 407-430, https://doi.org/10.5194/tc-6-407-2012, 2012.

Hugelius, G., Strauss, J., Zubrzycki, S., Harden, J. W., Schuur, E. A. G., Ping, C. L., Schirrmeister, L., Grosse, G., Michaelson, G. J., Koven, C. D., O’Donnell, J. A., Elberling, B., Mishra, U., Camill, P., Yu, Z., Palmtag, J., and Kuhry, P.: Estimated stocks of circumpolar permafrost carbon with quantified uncertainty ranges and identified data gaps, Biogeosciences, 11, 6573-6593, https://doi.org/10.5194/bg-11-6573-2014, 2014.

Huntingford, C. and Cox, P. M.: An analogue model to derive additional climate change scenarios from existing GCM simulations, Clim. Dynam., 16, 575-586, 2000.
Huntingford, C., Harris, P. P., Gedney, N., Cox, P. M., Betts, R. A., Marengo, J. A., and Gash, J. H. C.: Using a GCM analogue model to investigate the potential for Amazonian forest dieback, Theor. Appl. Climatol., 78, 177-185, 2004.

Huntingford, C., Booth, B. B. B., Sitch, S., Gedney, N., Lowe, J. A., Liddicoat, S. K., Mercado, L. M., Best, M. J., Weedon, G. P., Fisher, R. A., Lomas, M. R., Good, P., Zelazowski, P., Everitt, A. C., Spessa, A. C., and Jones, C. D.: IMOGEN: an intermediate complexity model to evaluate terrestrial impacts of a changing climate, Geosci. Model Dev., 3, 679-687, https://doi.org/10.5194/gmd-3-679-2010, 2010.

Huntingford, C., Zelazowski, P., Galbraith, D., Mercado, L. M., Sitch, S., Fisher, R., Lomas, M., Walker, A. P., Jones, C. D., Booth, B. B., and Malhi, Y.: Simulated resilience of tropical rainforests to $\mathrm{CO}_{2}$-induced climate change, Nat. Geosci., 6, 268273, 2013.

IPCC: Climate Change 2013: The Physical Science Basis, in: Contribution of Working Group I to the Fifth Assessment Report of the Intergovernmental Panel on Climate Change, edited by: Stocker, T. F., Qin, D., Plattner, G.-K., Tignor, M., Allen, S. K., Boschung, J., Nauels, A., Xia, Y., Bex, V., and Midgley, P. M., Cambridge University Press, Cambridge, UK and New York, NY, USA, 1535 pp., https://doi.org/10.1017/CBO9781107415324, 2013.

Ito, A., Nishina, K., and Noda, H. M.: Impacts of future climate change on the carbon budget of northern high-latitude terrestrial ecosystems: An analysis using ISI-MIP data, Polar Science, 10, 346-355, https://doi.org/10.1016/j.polar.2015.11.002, 2016.

Jones, C. and Sellar, A.: Development of the 1st version of the UK Earth system model, http://www.jwcrp.org.uk/research-activity/ ukesm-devesm.asp (last access: 13 June 2017), 2016.

Jones, C., McConnell, C., Coleman, K., Cox, P., Falloon, P., Jenkinson, D., and Powlson, D.: Global climate change and soil carbon stocks; predictions from two contrasting models for the turnover of organic carbon in soil, Global Change Biol., 11, 154-166, 2005.

Jones, C., Robertson, E., Arora, V., Friedlingstein, P., Shevliakova, E., Bopp, L., Brovkin, V., Hajima, T., Kato, E., Kawamiya, M., Liddicoat, S., Lindsay, K., Reick, C., Roelandt, C., Segschneider, J., and Tjiputra, J.: 21st century compatible $\mathrm{CO}_{2}$ emissions and airborne fraction simulated by CMIP5 earth system models under 4 representative concentration pathways, J. Climate, 26, 43984413, https://doi.org/10.1175/JCLI-D-12-00554.1, 2013.

Klein Goldewijk, K.: Estimating global land use change over the past 300 years: the HYDE database, Global Biogeochem. Cy. 15, 417-434, 2001.

Koven, C. D., Friedlingstein, P., Ciais, P., Khvorostyanov, D., Krinner, G., and Tarnocai, C.: On the formation of high-latitude soil carbon stocks: Effects of cryoturbation and insulation by organic matter in a land surface model, Geophys. Res. Lett., 36, L21501, https://doi.org/10.1029/2009GL040150, 2009.

Koven, C. D., Ringeval, B., Friedlingstein, P., Ciais, P., Cadule, P., Khvorostyanov, D., Krinner, G., and Tarnocai, C.: Permafrost carbon-climate feedbacks accelerate global warming, P. Natl. Acad. Sci. USA, 108, 14769-14774, 2011.

Koven, C. D., Riley, W. J., and Stern, A.: Analysis of permafrost thermal dynamics and response to climate change in the CMIP5 Earth System Models, J. Climate, 26, 1877-1900, 2013. 
Koven, C. D., Schuur, E. A. G., Schädel, C., Bohn, T. J., Burke, E. J., Chen, G., Chen, X., Ciais, P., Grosse, G., Harden, J. W., Hayes, D. J., Hugelius, G., Jafarov, E. E., Krinner, G., Kuhry, P., Lawrence, D. M., MacDougall, A. H., Marchenko, S. S., McGuire, A. D., Natali, S. M., Nicolsky, D. J., Olefeldt, D., Peng, S., Romanovsky, V. E., Schaefer, K. M., Strauss, J., Treat, C. C., and Turetsky, M.: A simplified, data-constrained approach to estimate the permafrost carbon-climate feedback, Philos. T. Roy. Soc. A, 373, https://doi.org/10.1098/rsta.2014.0423, 2015a.

Koven, C. D., Lawrence, D. M., and Riley, W. J.: Permafrost carbon-climate feedback is sensitive to deep soil carbon decomposability but not deep soil nitrogen dynamics, P. Natl. Acad. Sci. USA, 112, 3752-3757, 2015b.

MacDougall, A. H. and Knutti, R.: Projecting the release of carbon from permafrost soils using a perturbed parameter ensemble modelling approach, Biogeosciences, 13, 2123-2136, https://doi.org/10.5194/bg-13-2123-2016, 2016.

MacDougall, A. H., Avis, C. A., and Weaver, A. J.: Significant contribution to climate warming from the permafrost carbon feedback, Nat. Geosci., 5, 719-721, 2012.

MacDougall, A. H., Eby, M., and Weaver, A. J.: If anthropogenic $\mathrm{CO}_{2}$ emissions cease, will atmospheric $\mathrm{CO}_{2}$ concentration continue to increase?, J. Climate, 26, 9563-9576, 2013.

Meinshausen, M., Smith, S. J., Calvin, K., Daniel, J. S., Kainuma, M. L. T., Lamarque, J. F., Matsumoto, K., Montzka, S. A., Raper, S. C. B., Riahi, K., and Thomson, A. G. J. M. V.: The RCP greenhouse gas concentrations and their extensions from 1765 to 2300 , Climatic Change, 109, 213-241, 2011.

Moss, R. H., Edmonds, J. A., Hibbard, K. A., Manning, M. R., Rose, S. K., Van Vuuren, D. P., Carter, T. R., Emori, S., Kainuma, M., Kram, T., and Meehl, G. A.: The next generation of scenarios for climate change research and assessment, Nature, 463, 747-756, 2010.

Parton, W. J., McKeown, B., Kirchner, V., and Ojima, D. S.: CENTURY Users Manual. Colorado State University, NREL Publication, Fort Collins, Colorado, USA, 1992.

Qian, H., Joseph, R., and Zeng, N.: Enhanced terrestrial carbon uptake in the Northern High Latitudes in the 21 st century from the Coupled Carbon Cycle Climate Model Intercomparison Project model projections, Global Change Biol., 16, 641-656, 2010.
Schädel, C., Schuur, E. A., Bracho, R., Elberling, B., Knoblauch, C., Lee, H., Luo, Y., Shaver, G. R., and Turetsky, M. R.: Circumpolar assessment of permafrost $\mathrm{C}$ quality and its vulnerability over time using long-term incubation data, Global Change Biol., 20, 641-652, 2014.

Schädel, C., Bader, M. K. F., Schuur, E. A., Biasi, C., Bracho, R., Čapek, P., De Baets, S., Diáková, K., Ernakovich, J., EstopAragones, C., and Graham, D. E.: Potential carbon emissions dominated by carbon dioxide from thawed permafrost soils, Nat. Clim. Change, 6, 950-953, 2016.

Schaefer, K., Zhang, T., Bruhwiler, L., and Barrett, A. P.: Amount and timing of permafrost carbon release in response to climate warming, Tellus B, 63, 165-180, 2011.

Schneider von Deimling, T., Meinshausen, M., Levermann, A., Huber, V., Frieler, K., Lawrence, D. M., and Brovkin, V.: Estimating the near-surface permafrost-carbon feedback on global warming, Biogeosciences, 9, 649-665, https://doi.org/10.5194/bg-9649-2012, 2012.

Schneider von Deimling, T., Grosse, G., Strauss, J., Schirrmeister, L., Morgenstern, A., Schaphoff, S., Meinshausen, M., and Boike, J.: Observation-based modelling of permafrost carbon fluxes with accounting for deep carbon deposits and thermokarst activity, Biogeosciences, 12, 3469-3488, https://doi.org/10.5194/bg12-3469-2015, 2015.

Schuur, E. A. G., McGuire, A. D., Schädel, C., Grosse, G., Harden, J. W., Hayes, D. J., Hugelius, G., Koven, C. D., Kuhry, P., Lawrence, D. M., and Natali, S. M.: Climate change and the permafrost carbon feedback, Nature, 520, 171-179, 2015.

Wang, T., Ottlé, C., Boone, A., Ciais, P., Brun, E., Morin, S., Krinner, G., Piao, S., and Peng, S.: Evaluation of an improved intermediate complexity snow scheme in the ORCHIDEE land surface model, J. Geophys. Res.-Atmos., 118, 6064-6079, 2013.

Weedon, G. P., Gomes, S., Viterbo, P., Shuttleworth, W. J., Blyth, E., Österle, H., Adam, J. C., Bellouin, N., Boucher, O., and Best, M.: Creation of the WATCH forcing data and its use to assess global and regional reference crop evaporation over land during the twentieth century, J. Hydrometeorol., 12, 823-848, 2011. 